\title{
Review
}

\section{$\beta$-Adrenergic receptor subtype signaling in heart: From bench to bedside}

\author{
Anthony Yiu Ho WOO ${ }^{1,2}$, Rui-ping XIAO, 2, * \\ ${ }^{1}$ Institute of Molecular Medicine, Center for Life Sciences, Peking University, Beijing 100871, China; ${ }^{2}$ Drug Discovery Center, School of \\ Chemical Biology and Biotechnology, Peking University Shenzhen Graduate School, Shenzhen 518055, China
}

$\beta$-Adrenergic receptor ( $\beta A R$ ) stimulation by the sympathetic nervous system or circulating catecholamines is broadly involved in peripheral blood circulation, metabolic regulation, muscle contraction, and central neural activities. In the heart, acute $\beta A R$ stimulation serves as the most powerful means to regulate cardiac output in response to a fight-or-flight situation, whereas chronic $\beta A R$ stimulation plays an important role in physiological and pathological cardiac remodeling.

There are three $\beta A R$ subtypes, $\beta_{1} A R, \beta_{2} A R$ and $\beta_{3} A R$, in cardiac myocytes. Over the past two decades, we systematically investigated the molecular and cellular mechanisms underlying the different even opposite functional roles of $\beta_{1} A R$ and $\beta_{2} A R$ subtypes in regulating cardiac structure and function, with keen interest in the development of novel therapies based on our discoveries. We have made three major discoveries, including (1) dual coupling of $\beta_{2} A R$ to $G_{s}$ and $G_{i}$ proteins in cardiomyocytes, (2) cardioprotection by $\beta_{2} A R$ signaling in improving cardiac function and myocyte viability, and (3) PKA-independent, CaMKII-mediated $\beta_{1} A R$ apoptotic and maladaptive remodeling signaling in the heart. Based on these discoveries and salutary effects of $\beta_{1} A R$ blockade on patients with heart failure, we envision that activation of $\beta_{2} A R$ in combination with clinically used $\beta_{1} A R$ blockade should provide a safer and more effective therapy for the treatment of heart failure.

Keywords: $\beta$-adrenergic receptor; heart failure; signal transduction; cardiovascular system

Acta Pharmacologica Sinica (2012) 33: 335-341; doi: 10.1038/aps.2011.201; published online 30 Jan 2012

\section{Introduction}

Heart failure (HF) is a syndrome characterized by the insufficient pumping of blood to meet the need of the body. It is a chronic and severely debilitating disease with people older than 65 composed more than $75 \%$ of all cases ${ }^{[1]}$. Regardless of the cause, the failing heart usually ends up in a viscous cycle of progressive functional decline. Owing to its high prevalence, morbidity, mortality and significant health-care costs, HF represents a major current health problem in China and its prevalence is in an upward trend as atherothrombotic diseases, which often lead to HF, will be the first cause of death in the world by $2020^{[2]}$.

In congestive HF, both the activities of the sympathetic nervous system and the renin-angiotensin system (RAS) are increased $^{[3]}$. Initially, the increased activity of these neurohormonal systems serves to compensate for the reduced blood pressure and cardiac output. But long term exposure to high

\footnotetext{
* To whom correspondence should be addressed.

E-mail xiaor@pku.edu.cn

Received 2011-11-16 Accepted 2011-12-19
}

levels of circulating catecholamines and angiotensin increases the workload of the heart, and causes maladaptive cardiac remodeling and myocyte death ${ }^{[4-6]}$. Many of these effects appear to be mediated by the signal transduction cascades of the receptors involved.

$\beta$-Adrenergic receptor $(\beta A R)$ and angiotensin receptor belong to the superfamily of $G$ protein-coupled receptors (GPCRs) or seven transmembrane receptors. GPCRs constitute the most ubiquitous of plasma membrane receptors. They are involved in the regulation of many important physiological functions and also serve as the most important drug targets $^{[7]}$. Over the past 25 years, $\beta$ AR antagonists ( $\beta$-blockers), angiotensin converting enzyme inhibitors (ACEIs) and angiotensin II receptor blockers (ARBs), alone or in combination, have been used to treat HF conditions. Their use ameliorates the deterioration of left ventricular function, improves symptoms and hemodynamics, and decreases the mortality rate and the need for hospitalization ${ }^{[8-11]}$. However, these therapeutic agents have limited effectiveness in some patient populations and they also have some adverse effects. Therefore, there is a compelling need to develop new treatments that can improve clinical outcomes. 


\section{Subtype-specific $\beta$ AR signaling in the heart}

$\beta$ ARs exist as three subtypes, $\beta_{1}, \beta_{2}$, and $\beta_{3}$, and the former two are important in the regulation of excitation-contraction coupling of myocardium. $\beta_{1} \mathrm{AR}$ is the predominant receptor subtype expressed in the heart. Its stimulation results in the activation of the $\mathrm{G}_{\mathrm{s}}$-adenylyl cyclase (AC)-cAMP-protein kinase A (PKA) signaling cascade. In ventricular myocytes, the phosphorylation of PKA substrates including phospholamben, L-type calcium channel, ryanodine receptor, cardiac troponin $\mathrm{I}$, and cardiac myosin-binding protein $\mathrm{C}$ results in the increase in calcium transient and contractility. In pacemaker cells, PKA-mediated phosphorylation of membrane ion channels and $\mathrm{Ca}^{2+}$ handling proteins increases $\mathrm{Ca}^{2+}$ cycling and pacing rate. Similarly, $\beta_{2} \mathrm{AR}$ also has a functional role in cardiomyocyte contraction $^{[12]}$. But unlike $\beta_{1} \mathrm{AR}$ which couples only to $G_{s}, \beta_{2} A R$ also couples to pertussis toxin (PTX)-sensitive $G_{i}$ proteins ${ }^{[13]}$. The $\beta_{2} A R-G_{i}$ signaling has negative effects on AC activity, cAMP synthesis, PKA activation, and the inotropic response mediated by $\mathrm{G}_{\mathrm{s}}$.

Importantly, persistent stimulation of $\beta_{1} \mathrm{AR}$ and $\beta_{2} \mathrm{AR}$ exhibits distinct outcomes under certain pathological circumstances such as HF. Specifically, persistent stimulation of $\beta_{1} \mathrm{AR}$ triggers cardiomyocyte apoptosis by a $\mathrm{Ca}^{2+} /$ calmodulin-dependent kinase II (CaMKII)-dependent, but PKA independent mechanism ${ }^{[14]}$. Furthermore, the $\beta_{1}$ AR-activated CaMKII signaling, but not the PKA pathway, is involved in catecholamine-induced cardiomyocyte hypertrophy in vitro ${ }^{[15]}$ and maladaptive cardiac remodeling in vivo ${ }^{[16,17]}$. In contrast to the cardiotoxic effects of persistent $\beta_{1} \mathrm{AR}$ activation, persistent $\beta_{2} \mathrm{AR}$ stimulation is cardioprotective. The cardioprotective effect of persistent $\beta_{2} \mathrm{AR}$ signaling is largely mediated by $\beta_{2}$ AR- $G_{i}$ coupling, which activates the $G_{\beta \gamma}$-phosphoinositol 3-kinase (PI3K)-Akt cell survival pathway ${ }^{[18]}$. Although beneficial in terms of cardiomyocyte viability, the protective effect of $\beta_{2} \mathrm{AR}$ comes at the cost of compromised contractile support.

\section{Heart failure-associated alterations in $\boldsymbol{\beta A R}$ signaling}

During HF, $\beta_{1} \mathrm{AR}$ is persistently downregulated at the mRNA and protein levels ${ }^{[19,20]}$. Its density on the plasma membrane is reduced by $50 \%$, while that of $\beta_{2} \mathrm{AR}$ has no such change ${ }^{[21]}$. The resulting change in the ratio of $\beta_{1} / \beta_{2} \mathrm{AR}$ from an 80:20 distribution in the healthy heart to a ratio of 60:40 in the failing heart may indicate the prominent role of $\beta_{2} \mathrm{AR}$ signaling in the disease condition. In the failing heart, the selective downregulation of $\beta_{1} A R$ is often associated with an upregulation of $G_{i}$ and an enhanced $\beta_{2} A R-G_{i}$ signaling ${ }^{[22,23]}$. Importantly, the $\beta_{1}$ AR-mediated contractile response is cross-inhibited by the enhanced $\beta_{2} A R-G_{i}$ signaling in the failing heart. Thus, the enhanced $\beta_{2} A R-G_{i}$ signaling contributes to the dysfunction of both $\beta_{1} A R-$ and $\beta_{2} A R-G_{s}$ signaling in the failing heart ${ }^{[24-27]}$.

In addition, the signaling efficiency of $\beta_{1} A R$ is also markedly reduced in the failing heart as a result of desensitization $^{[28]}$. This is attributed, in part, to a significant increase in the expression level of $G$ protein coupled receptor kinase 2 $(\mathrm{GRK} 2)^{[29]}$, the prototypical member of the GRK family. The process of $\beta A R$ desensitization involves a series of events, including (a) the translocation of GRK2 to the plasma membrane facilitated by the free $G_{\beta \gamma}$ subunits liberated from the activated heterotrimeric $G$ proteins ${ }^{[30]}$, (b) the phosphorylation of the serine or threonine residues on the C-terminal tail of $\beta$ ARs by GRK2, (c) the recruitment of $\beta$-arrestins to the phosphorylated receptor, the physical displacement of $G_{s \alpha}$ from the $\beta$-arrestin-associated receptor, and (d) the $\beta$-arrestindependent internalization of the receptor (endocytosis) ${ }^{[31]}$. While $\beta_{2} \mathrm{AR}$ stays at a similar level in the failing heart, its coupling efficiency to $G_{s}$ is markedly reduced ${ }^{[21]}$. Desensitization of $\beta$ ARs leads to reduced $G_{s}$-mediated responses such as cAMP production and positive inotropic effect. Although receptor downregulation and desensitization are considered to be protective responses against excessive sympathetic stimulation during $\mathrm{HF}^{[32,33]}$, the resultant abnormality in $\beta \mathrm{AR}$ signaling may lead to the activation of signaling pathways that are involved in cardiac remodeling, such as the PI3K cascades ${ }^{[34]}$.

Indeed, in humans or animal models with HF, chronic catecholamine elevation causes marked dysregulation of $\beta$ ARs, resulting in various molecular abnormalities, including the upregulation of GRK2 ${ }^{[29,35]}$ and $\mathrm{G}_{i}$ proteins ${ }^{[22,23,36]}$. Upregulation of both of these proteins have been implicated as causal factors in the development of HF. In particular, GRK2 is the most abundant and best-characterized GRK in the heart ${ }^{[37]}$. GRK2 expression and activity are markedly elevated and play a central role in the HF-associated defect in $\beta A R$ signaling ${ }^{[38]}$ and cardiac dysfunction ${ }^{[39]}$. Myocardial ischemia and hypertension in humans and animal models have also been associated with elevated GRK2 expression and activity ${ }^{[40,41]}$. These previous studies have defined GRK2 upregulation as an early common event in cardiac maladaptive remodeling and HF.

Emerging evidence suggests that activation of GRK2 as well as PKA is essentially involved in the activation of the $\beta_{2}$ AR-coupled $G_{i}$ signaling in mammalian cells. First, early work has shown that $\beta_{2} A R$-induced activation of ERK1/2 in HEK293 cells is mediated by a $\mathrm{G}_{\mathrm{i}}$-dependent mechanism, and that phosphorylation of $\beta_{2} A R$ by PKA is a prerequisite for the switch of the receptor coupling from $G_{s}$ to $G_{i}^{[42]}$. Second, our recent studies ${ }^{[43]}$ have demonstrated that elevated $\beta_{2} A R$ phosphorylation by GRK2 acerbates the $G_{i}$ signaling, whereas inhibition of GRK2 activity profoundly suppresses the $\beta_{2} \mathrm{AR}-\mathrm{G}_{\mathrm{i}}$ coupling. Since GRK2 upregulation occurs prior to the onset of $\mathrm{HF}$ and contributes to the development of $\mathrm{HF}^{[44,45]}$, enhanced GRK2 activation may play an important role in the exacerbated $\beta_{2} A R$-coupled $G_{i}$ signaling in the failing heart. Indeed, disruption of $G_{i}$ signaling with PTX or inhibition of GRK2 with a peptide inhibitor, $\beta$ ARK-ct, can restore cardiac contractile response to $\beta \mathrm{AR}$ stimulation in multiple HF models $^{[46-49]}$.

Importantly, cardiac-specific transgenic overexpression of a mutant $\beta_{2} \mathrm{AR}$ lacking PKA phosphorylation sites (PKA-TG), but not the wild type $\beta_{2} \mathrm{AR}$ (WT TG) or a mutant $\beta_{2} \mathrm{AR}$ lacking GRK sites (GRK-TG), led to exaggerated cardiac response to pressure overload, as manifested by markedly exacerbated cardiac maladaptive remodeling and failure, and early mortality ${ }^{[43]}$. Furthermore, inhibition of $G_{i}$ signaling with PTX 
restores cardiac function in $\mathrm{HF}$ associated with increased $\beta_{2} \mathrm{AR}$ to $G_{i}$ coupling induced by removing PKA phosphorylation of the receptor and in GRK2 transgenic mice, indicating that enhanced phosphorylation of $\beta_{2} \mathrm{AR}$ by GRK and resultant increase in $\mathrm{G}_{\mathrm{i}}$-biased $\beta_{2} \mathrm{AR}$ signaling play an important role in the development of $\mathrm{HF}^{[43]}$. Altogether, our recent studies have demonstrated that enhanced $\beta_{2} \mathrm{AR}$ phosphorylation by GRK leads the receptor to $\mathrm{G}_{\mathrm{i}}$-biased signaling which, in turn, contributes to the pathogenesis of $\mathrm{HF}$, marking $\mathrm{G}_{\mathrm{i}}$-biased $\beta_{2} \mathrm{AR}$ signaling as a primary event linking pathological upregulation of GRK to cardiac maladaptive remodeling, failure and cardiodepression. It is also noteworthy that, as is the case in the failing heart, enhanced $\beta_{2}$ AR-coupled $G_{i}$ signaling is responsible for the defects of both $\beta_{1} \mathrm{AR}$ and $\beta_{2} \mathrm{AR}$ signaling in the GRK2 transgenic mice ${ }^{[43]}$, and that the previously reported beneficial effects of $\beta$ ARK-ct in improving the function of the failing heart ${ }^{[38,39,50-52]}$ is mediated, at least in part, by attenuating GRK-dependent $G_{\mathrm{i}}$-biased $\beta_{2}$ AR signaling.

\section{Carvedilol paradox}

In clinical settings, long-term use of $\beta$-blockers improves clinical symptom of HF. Treatment with $\beta$-blockers improves left ventricular contractile function in the failing heart and reverses cardiac remodeling ${ }^{[8,9]}$. In the molecular level, $\beta$-blockade may normalize $\beta$ AR system through the upregulation of $\beta_{1} A R^{[53]}$ and the restoration of receptor sensitivity by decreasing the expression of GRK2 ${ }^{[50]}$. However, the effects of different $\beta$-blockers are not identical. The use of subtype nonselective $\beta$-blockers in early years has caused some major side effects including bronchial and blood vessel constriction ${ }^{[54,55]}$. This is largely due to the inhibition of $\beta_{2} \mathrm{AR}$ in non-cardiac tissues such as the respiratory system and blood vessels. These problems have been partially resolved with the introduction of selective $\beta_{1} \mathrm{AR}$ antagonists, such as atenolol, metoprolol, bisoprolol and nebivolol. Recent clinical trials have indicated that only 3 out of $16 \beta$-blockers are beneficial in terms of cardiovascular survival ${ }^{[9,56-58]}$, with carvedilol emerging as the best ${ }^{[59]}$.

Apart from being a non-selective $\beta$-blocker, carvedilol also has several properties, such as $\alpha_{1}$-adrenergic blockade, antioxidant, anti-proliferative, anti-endothelin and anti-arrythmogenic effects ${ }^{[60,61]}$, which may explain its higher efficacy. Interestingly, carvedilol has been found to be the only one among 16 blockers that activated ERK by a $\beta_{2}$ AR-mediated, G protein-independent, and $\beta$-arrestin-dependent mechanism ${ }^{[2]}$. Moreover, among $20 \beta$-blockers tested, only atenolol and carvedilol could induce the $\beta_{1}$ AR-mediated transactivation of EGFR and this effect is also $\beta$-arrestin-dependent ${ }^{[63]}$. It has been implicated that this effect may contribute to the special therapeutic effect of carvedilol. In this regard, recent studies have shown that $\beta$-arrestin-dependent, $G$ protein-independent activation of EGFR via $\beta_{1}$ AR confers cardioprotection in mice chronically stimulated with catecholamine ${ }^{[64]}$. These data suggest that a ligand can antagonize the $\mathrm{G}$ protein-dependent activity of a GPCR and at the same time stimulates signaling pathways in a $G$ protein-independent $\beta$-arrestin-dependent fashion ${ }^{[6]}$. They are also of great relevance to our discussion in the next section about the application of this principle in the development of novel therapeutic agents.

\section{Biased $\beta A R$ signaling and drug discovery}

In the classical paradigm of GPCR signaling, ligand binding leads to conformational change of the receptor from an inactive state $R$ into a single activated state $R^{*}$ that results in the coupling of the receptor to heterotrimeric $G$ proteins. Receptor coupling facilitates the exchange of the bound GDP with GTP in the a subunit of the $\mathrm{G}$ protein complex. This triggers dissociation of the complex into $G_{\alpha}$ and $G_{\beta \gamma}$ subunits. They go on to activate their respective effectors such as $\mathrm{AC}$, phospholipases and ion channels. These receptor mediated reactions often generate signaling molecules called second messengers which activate or inhibit other components of the cellular machinery. Thus, receptor stimulation produces a multitude of cellular responses via the activation of the signal transduction pathways downstream of $G$ proteins. Agonist efficacy, a measure of the ability of an agonist to activate this cascade, quantitatively defines the agonist as partial or full. In this scheme, antagonist is defined as a ligand which binds to the receptor but produces no receptor activation and thus has the ability to block agonist-stimulated $\mathrm{G}$ protein activation. This unidirectional understanding of agonist efficacy is contradictory to the aforementioned findings that a ligand for a single GPCR can be an antagonist for the $G$ protein-dependent signals and also an agonist for the $\beta$-arrestin-dependent signals ${ }^{[2,63]}$.

Over the past fifteen years, more and more evidence has accumulated indicating that a ligand for a given GPCR does not simply possess a single defined efficacy. Rather, a ligand possesses multiple efficacies, depending on the downstream signal transduction pathways analyzed. Moreover, GPCR can be differentially activated to target a specific subset of signal transduction pathways by the so-called "biased ligand". In particular, research has revealed that GPCR can be stimulated to produce a $\beta$-arrestin-dependent but $G$ protein-independent signal, which differs both spatially and temporally from the $\beta$-arrestin-mediated signal stemmed from receptor desensitization $^{[6]]}$. It is believed that the $\beta$-arrestin-biased ligand activates the alternative signaling pathway by stabilizing the receptor in a distinct active conformation $R^{*^{\prime}}$. Thus, in this new paradigm, GPCR may be stabilized by different ligands in distinct active conformations $R^{* 1}-R^{* n}$ each capable of activating a diverse array of signal transduction pathways and responses (Figure 1). This concept, described as functional selectivity, collateral/pluridimensional efficacy, or biased agonism, has major implications for pharmacological therapeutics ${ }^{[65,67-70]}$.

To add another layer of complexity to this scheme, the signal trafficked by a biased agonist is context-dependent, too. Not only does the selectivity of a ligand towards different signaling pathways change in different cell types, the change in the levels of cytosolic reactants of GPCR also has an impact on the functional selectivity of a ligand. For example, the specific $\beta_{2} \mathrm{AR}$ antagonist ICI-118551 has been suggested to directly produce a negative inotropic effect by acting as an agonist for the $\mathrm{G}_{\mathrm{i}}$-coupled $\beta_{2} \mathrm{AR}$ in myocytes from failing human heart ${ }^{[7]}$. 


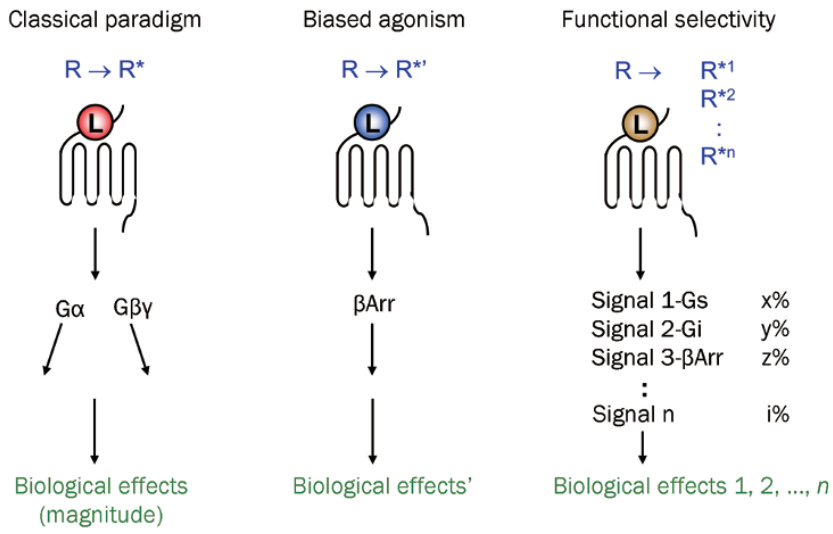

Figure 1. Development of the receptor theory. In the classical paradigm, ligands have linear efficacies, referring to their abilities to stabilize the receptor into a single active state. The emerging concept of biased agonism suggests that a biased ligand may stabilize the receptor into a distinct active state that does not activate $G$ proteins but activates $\beta$-arrestins. In the concept of functional selectivity, receptors may exist in multiple active conformations as stabilized by different ligands, and each of these conformations gives rise to different downstream signals and biological effects. $\beta$ Arr, $\beta$-arrestin; L, ligand; R, inactive conformation of GPCR; $R^{*}$, active conformation of GPCR.

This effect is not due to the blocking of the endogenous catecholamines and is also different in principle from an inverse agonistic effect also described for this ligand ${ }^{[72]}$. It is because this negative inotropic effect of ICI-118551 is PTX-sensitive, is observable at receptor levels with or without overexpression manipulation, and only becomes apparent under the conditions when the levels of $G_{i}$ are raised.

In a recent study using a cardiomyocyte model ${ }^{[49]}$, we have screened a panel of $\beta_{2} \mathrm{AR}$ agonists, including zinterol, salbutamol, and procaterol for their receptor-mediated contractility stimulatory activities and the sensitivities of these effects towards PTX. We have found that PTX augmented the contractile responses of most $\beta_{2} \mathrm{AR}$ agonists but not that of fenoterol. These data indicates that while most $\beta_{2} A R$ agonists activate both $\mathrm{G}_{\mathrm{s}}$ and $\mathrm{G}_{\mathrm{i}}$, fenoterol selectively activates $\mathrm{G}_{\mathrm{s}}$. This is the first evidence to show that different agonists can activate a receptor to couple to different G-proteins. It was further found that fenoterol fully reversed the diminished $\beta_{2} \mathrm{AR}-$ mediated inotropic effect in cardiomyocytes isolated from failing spontaneous hypertensive rat hearts even in the absence of PTX. This study is particularly valuable in that fenoterol was identified to be a unique agonist capable of selectively stabilizing the coupled $\beta_{2} A R-G_{s}$ species in conditions that favor $\beta_{2} A R-G_{i}$ coupling. It also reveals the therapeutic potential of fenoterol in the treatment of HF.

The effectiveness of fenoterol in treating HF conditions has been demonstrated in a number of follow-up in vivo studies $^{[73-76]}$. Prolonged use of fenoterol not only improves cardiac function, but also retards cardiac maladaptive remodeling, and that the overall beneficial effects of fenoterol are greater than the salutary effects of $\beta_{1} A R$ blockade in a myocardial infarction induced rat model of dilated cardiomyopathy ${ }^{[73]}$. These studies suggest that selective activation of the $\beta_{2}$-AR-coupled $\mathrm{G}_{\mathrm{s}}$ signaling may provide a useful therapeutic target for the treatment of congestive HF. We envision that new $\mathrm{G}_{\mathrm{s}}$-biased $\beta_{2} \mathrm{AR}$ agonists, such as fenoterol and its derivatives, may be developed into drugs to improve the structure and function of the failing heart.

Fenoterol contains two chiral centers and can exist as four stereoisomers. We have synthesized a cohort of fenoterol derivatives including the $R, R-, R, S-, S, R$-, and $S, S$-isomers ${ }^{[77,78]}$. While the pharmaceutical preparation of fenoterol is a racemic mixture of its $R, R$ - and $S, S$-enantiomers, our recent studies have shown that the $R, R$-enantiomer is the only active isomer in receptor binding and cardiomyocyte contraction assays ${ }^{[77,78]}$. It has been known for a century that stereoisomers of catecholamines differ in their potency and efficacy. However, the molecular basis for the differences in the efficacies of GPCR ligand stereoisomers has remained poorly defined. We have, therefore, used some of these fenoterol derivatives to examine the hypothesis that the stereochemistry of an agonist determines functional selectivity of a given receptor coupling to different $G$ protein(s) and resultant activation of subset(s) of downstream signaling pathways ${ }^{[79]}$. We found that while $\mathrm{R}$, R-fenoterol failed to activate $\mathrm{G}_{\mathrm{i}}$ signaling, as evidenced by the absence of PTX-sensitivity of its contractile response and its inability to activate $\mathrm{G}_{\mathrm{i}}$-dependent ERK1/2 signaling, S,Rfenoterol exhibited a robust PTX-sensitivity in these responses, suggesting that the S,R-isomer enables $\beta_{2} \mathrm{AR}$ to activate both $\mathrm{G}_{\mathrm{s}}$ and $\mathrm{G}_{\mathrm{i}}$. The same conclusion holds true for some fenoterol derivatives. For instance, S,R-methoxyfenoterol, but not R,Rmethoxyfenoterol, activated $\beta_{2}$ AR-coupled $G_{i}$ signaling in cardiomyocytes $^{[79]}$. Thus, in addition to receptor subtype and phosphorylation status, the different stereoisomers of an agonist selectively activate distinct receptor-G protein interactions and downstream signaling events. This finding is important because it is the first account to show that even the subtle chemical differences within a ligand stereoisomer pair are sufficient to stabilize GPCR conformations with distinct G-protein coupling properties, highlighting how important it is to carefully examine both the "active" and the "inactive" stereoisomer to understand the exact mechanism of action and cellular effects of a GPCR ligand ${ }^{[80]}$.

This finding also has important clinical implications. In particular, it has been shown that long-term ( 1 year) treatment with racemic fenoterol enhances the beneficial effect of $\beta_{1} A R$ blockade with metoprolol in a rat model of dilated cardiomyopathy ${ }^{[75]}$, and the combined (fenoterol+metoprolol) therapy is as good as the clinical combination (metoprolol+ACEI) treatment with respect to mortality, and exceeds the latter with respect to cardiac remodeling and myocardial infarct expan$\operatorname{sion}^{[76]}$. It will be interesting to study the effects of different fenoterol derivatives ${ }^{[77,78,81]}$ alone or in combination with $\beta_{1} \mathrm{AR}$ blocker or RAS inhibitor in this model. Continued efforts on this research line may lead to the development of potential novel therapies with greater selectivity, efficacy and fewer side 
effects for human congestive HF. Topics related to the translation of this novel treatment regimen have been discussed extensively in another recent review ${ }^{[82]}$, which also contains a pathway map for $\beta A R$ subtype signaling described in this article.

If suppression of $\beta_{2} A R-G_{i}$ signaling or enhancement of $\beta_{2} A R-G_{s}$ signaling is beneficial in $H F$, the next question is: what is the difference between $\beta_{2} A R-G_{s}$ signaling and $\beta_{1} A R-G_{s}$ signaling? In a recent elegant study ${ }^{[83]}$, Mangmool and coauthors have elucidated the molecular mechanism of CaMKII activation by $\beta_{1} A R$. They found that stimulation of $\beta_{1} A R$ induces the formation of a $\beta$-arrestin-CaMKII-Epac1 complex, allowing its recruitment to the plasma membrane, and whereby promotes cAMP-dependent activation of CaMKII. Further studies using chimeric receptors with switched carboxyl-terminal tails of $\beta_{1} \mathrm{AR}$ or $\beta_{2} \mathrm{AR}$ suggested that $\beta$-arrestin binding to the carboxyl-terminal tail of $\beta_{1} A R$ promotes a conformational change within $\beta$-arrestin that allows CaMKII and Epac to remain in a stable complex with the receptor. These results demonstrate that only $\beta_{1} \mathrm{AR}$ but not $\beta_{2} \mathrm{AR}$ activates CaMKII significantly. As $\mathrm{CaMKII}_{\delta}$ is a common intermediate of diverse death stimuli-induced apoptosis in cardiomyocytes $^{[84]}$, is required for the transition from pressure overloadinduced cardiac hypertrophy to $\mathrm{HF}^{[85]}$, and promotes lifethreatening arrythmias in $\mathrm{HF}^{[86]}$, this explains why activation of $\beta_{2} A R-G_{s}$ signaling is usually not accompanied with the adverse effects observed in $\beta_{1} \mathrm{AR}$ stimulation.

The molecular mechanism of the cardioprotective effect of $\beta_{2} A R-G_{s}$ signaling in HF is unclear. One possibility is the crosstalk of the $\mathrm{G}_{\mathrm{s}}-\mathrm{AC}$-cAMP-PKA cascade to the tyrosine kinase receptor-mediated Akt phosphorylation ${ }^{[87-89]}$.

\section{Concluding remark}

In summary, recent studies have revealed opposing functional roles of $\beta_{1} \mathrm{AR}$ and $\beta_{2} \mathrm{AR}$ in regulating myocyte viability and myocardial remodeling with a cardiac protective effect of $\beta_{2} \mathrm{AR}$ stimulation and a detrimental effect of $\beta_{1} \mathrm{AR}$ stimulation. Unlike the sole $G_{s}$ coupling of $\beta_{1} A R, \beta_{2} A R$ couples to both $G_{s}$ and $G_{i}$ signaling pathways with the $G_{i}$ coupling negating the $\mathrm{G}_{\mathrm{s}}$-mediated contractile support. In the failing heart, enhanced expression and activity of GRK2 and $\mathrm{G}_{\mathrm{i}}$ proteins further promote $G_{i}$-biased $\beta_{2} A R$ signaling, thus blunting both $\beta_{1} A R$ - and $\beta_{2}$ AR-mediated cardiac reserve function, resulting in cardiac maladaptive remodeling and failure. These findings defined the $\beta_{2} A R-G_{i}$ signaling as an essential link between pathologic upregulation of GRK and the development of HF. Since GRK2 and resultant $G_{i}$-biased $\beta_{2} A R$ signaling are pathogenic factors of $\mathrm{HF}, \mathrm{G}_{\mathrm{s}}$-biased $\beta_{2} \mathrm{AR}$ agonists may present an important therapeutic strategy for the treatment of HF caused by various etiologies.

\section{Acknowledgements}

This work was supported by the National Basic Research Program of China (2012CB518000) and the National Major Scientific Research Program of China (2012CB910400).

\section{References}

1 Rich MW. Epidemiology, pathophysiology, and etiology of congestive heart failure in older adults. J Am Geriatr Soc 1997; 45: 968-74.

2 Lloyd-Jones D, Adams RJ, Brown TM, Carnethon M, Dai S, De Simone G, et al. Executive summary: Heart disease and stroke statistics -2010 update: A report from the American Heart Association. Circulation 2010; 121: 948-54.

3 Levine TB, Francis GS, Goldsmith SR, Simon AB, Cohn JN. Activity of the sympathetic nervous system and renin-angiotensin system assessed by plasma hormone levels and their relation to hemodynamic abnormalities in congestive heart failure. Am J Cardiol 1982; 49: 1659-66.

4 Hasenfuss G, Mulieri LA, Allen PD, Just H, Alpert NR. Influence of isoproterenol and ouabain on excitation-contraction coupling, cross-bridge function, and energetics in failing human myocardium. Circulation 1996; 94: 3155-60.

5 Teerlink JR, Pfeffer JM, Pfeffer MA. Progressive ventricular remodeling in response to diffuse isoproterenol-induced myocardial necrosis in rats. Circ Res 1994; 75: 105-13.

6 Blaufarb IS, Sonnenblick EH. The renin-angiotensin system in left ventricular remodeling. Am J Cardiol 1996; 77: 8C-16C.

7 Overington JP, Al-Lazikani B, Hopkins AL. How many drug targets are there? Nat Rev Drug Disc 2006; 5: 993-6.

8 McMurray JJ, Pfeffer MA. Heart failure. Lancet 2005; 365: 1877 89.

9 Waagstein F, Bristow MR, Swedberg K, Camerini F, Fowler MB, Silver $M A$, et al. Beneficial effects of metoprolol in idiopathic dilated cardiomyopathy. Metoprolol in Dilated Cardiomyopathy (MDC) Trial Study Group. Lancet 1993; 342: 1441-6.

10 Beckwith C, Munger MA. Effect of angiotensin-converting enzyme inhibitors on ventricular remodeling and survival following myocardial infarction. Ann Pharmacother 1993; 27: 755-66.

11 Lee VC, Rhew DC, Dylan M, Badamgarav E, Braunstein GD, Weingarten SR. Meta-analysis: angiotensin-receptor blockers in chronic heart failure and high-risk acute myocardial infarction. Ann Intern Med 2004; 141: 693-704.

12 Xiao RP, Hohl C, Altschuld R, Jones L, Livingston B, Ziman B, et al. $\beta_{2^{-}}$ adrenergic receptor-stimulated increase in cAMP in rat heart cells is not coupled to changes in $\mathrm{Ca}^{2+}$ dynamics, contractility, or phospholamban phosphorylation. J Biol Chem 1994; 269: 19151-6.

13 Xiao RP, Ji X, Lakatta EG. Functional coupling of the $\beta_{2}$-adrenoceptor to a pertussis toxin-sensitive $G$ protein in cardiac myocytes. Mol Pharmacol 1995; 47: 322-9.

14 Zhu WZ, Wang SQ, Chakir K, Yang D, Zhang T, Brown JH, et al. Linkage of $\beta_{1}$-adrenergic stimulation to apoptotic heart cell death through protein kinase A-independent activation of $\mathrm{Ca}^{2+} /$ calmodulin kinase II. J Clin Invest 2003; 111: 617-25.

15 Sucharov CC, Mariner PD, Nunley KR, Long C, Leinwand, L, Bristow MR. A $\beta_{1}$-adrenergic receptor CaM kinase II-dependent pathway mediates cardiac myocyte fetal gene induction. Am J Physiol Heart Circ Physiol 2006; 291: H1299-308.

16 Bisognano JD, Weinberger HD, Bohlmeyer TJ, Pende A, Raynolds MV, Sastravaha A, et al. Myocardial-directed overexpression of the human $\beta_{1}$-adrenergic receptor in transgenic mice. J Mol Cell Cardiol 2000; 32: 817-30.

17 Engelhardt S, Hein L, Wiesmann F, Lohse MJ. Progressive hypertrophy and heart failure in $\beta 1$-adrenergic receptor transgenic mice. Proc Natl Acad Sci U S A 1999; 96: 7059-64.

18 Zhu WZ, Zheng M, Koch WJ, Lefkowitz RJ, Kobilka BK, Xiao RP. Dual modulation of cell survival and cell death by $\beta_{2}$-adrenergic signaling 
in adult mouse cardiac myocytes. Proc Natl Acad Sci U S A 2001; 98 : 1607-12.

19 Bristow MR, Ginsburg R, Fowler M, Minobe W, Rassmussen R, Zera $P$, et al. $\beta_{1}$ and $\beta_{2}$-adrenergic-receptor subpopulations in nonfailing and failing human ventricular myocardium: coupling of both receptor subtypes to muscle contraction and selective $\beta_{1}$-receptor downregulation in heart failure. Circ Res 1986; 59: 297-309.

20 Bristow MR, Minobe WA, Raynolds MV, Port JD, Rasmussen R, Ray PE, et al. Reduced $\beta_{1}$ receptor messenger RNA abundance in the failing human heart. J Clin Invest 1993; 92: 2737-45.

21 Bristow MR, Hershberger RE, Port JD, Minobe W, Rasmussen R. $\beta_{1^{-}}$ and $\beta_{2}$-adrenergic receptor-mediated adenylate cyclase stimulation in nonfailing and failing human ventricular myocardium. Mol Pharmacol 1989; 35: 295-303.

22 Bohm M, Eschenhagen T, Gierschik P, Larisch K, Lensche H, Mende $\mathrm{U}$, et al. Radioimmunochemical quantification of $\mathrm{G}_{\mathrm{i \alpha}}$ in right and left ventricles from patients with ischaemic and dilated cardiomyopathy and predominant left ventricular failure. J Mol Cell Cardiol 1994; 26 : 133-49.

23 Feldman AM, Cates AE, Veazey WB, Hershberger RE, Bristow MR, Baughman KL, et al. Increase of the 40 000-mol wt pertussis toxin substrate (G protein) in the failing human heart. J Clin Invest 1988; 82: 189-97.

24 Lokuta AJ, Maertz NA, Meethal SV, Potter KT, Kamp TJ, Valdivia HH, et al. Increased nitration of sarcoplasmic reticulum $\mathrm{Ca}^{2+}$-ATPase in human heart failure. Circulation 2005; 111: 988-95.

25 Sato M, Gong H, Terracciano CM, Ranu H, Harding SE. Loss of $\beta$-adrenoceptor response in myocytes overexpressing the $\mathrm{Na}^{+} / \mathrm{Ca}^{2+}$ exchanger. J Mol Cell Cardiol 2004; 36: 43-8.

26 Xiao RP, Balke CW. $\mathrm{Na}^{+} / \mathrm{Ca}^{2+}$ exchange linking $\beta_{2}$-adrenergic $\mathrm{G}_{i}$ signaling to heart failure: associated defect of adrenergic contractile support. J Mol Cell Cardiol 2004; 36: 7-11.

27 Zhu $W$, Zeng $X$, Zheng $M$, Xiao RP. The enigma of $\beta_{2}$-adrenergic receptor $G_{i}$ signaling in the heart: the good, the bad, and the ugly. Circ Res 2005; 97: 507-9.

28 Bristow MR, Ginsburg R, Minobe W, Cubicciotti RS, Sageman WS, Lurie K, et al. Decreased catecholamine sensitivity and $\beta$-adrenergicreceptor density in failing human hearts. N Engl J Med 1982; 307: 205-11.

29 Ungerer M, Bohm M, Elce JS, Erdmann E, Lohse MJ. Altered expression of $\beta$-adrenergic receptor kinase and $\beta_{1}$-adrenergic receptors in the failing human heart. Circulation 1993; 87: 454-63.

30 Pitcher JA, Inglese J, Higgins JB, Arriza JL, Casey PJ, Kim C, et al. Role of $\beta$ y subunits of $G$ proteins in targeting the $\beta$-adrenergic receptor kinase to membrane-bound receptors. Science 1992; 257: 1264-7.

31 Lefkowitz RJ. G protein-coupled receptors. III. New roles for receptor kinases and $\beta$-arrestins in receptor signaling and desensitization. J Biol Chem 1998; 273: 18677-80.

32 Faulx MD, Ernsberger P, Vatner D, Hoffman RD, Lewis W, Strachan $R$, et al. Strain-dependent $\beta$-adrenergic receptor function influences myocardial responses to isoproterenol stimulation in mice. Am J Physiol Heart Circ Physiol 2005; 289: H30-6.

33 Liggett SB, Cresci S, Kelly RJ, Syed FM, Matkovich SJ, Hahn HS, et al. A GRK5 polymorphism that inhibits $\beta$-adrenergic receptor signaling is protective in heart failure. Nat Med 2008; 14: 510-7.

34 Shioi T, Kang PM, Douglas PS, Hampe J, Yballe CM, Lawitts J, et al. The conserved phosphoinositide 3-kinase pathway determines heart size in mice. EMBO J 2000; 19: 2537-48.

35 Ungerer M, Parruti G, Böhm M, Puzicha M, DeBlasi A, Erdmann E, et al. Expression of $\beta$-arrestins and $\beta$-adrenergic receptor kinases in the failing human heart. Circ Res 1994; 74: 206-13.

36 Xiao RP, Avdonin P, Zhou YY, Cheng H, Akhter SA, Eschenhagen T, et al. Coupling of $\beta_{2}$-adrenoceptor to $G_{i}$ proteins and its physiological relevance in murine cardiac myocytes. Circ Res 1999; 84: 43-52.

37 Hata JA, Koch WJ. Phosphorylation of G protein-coupled receptors: GPCR kinases in heart disease. Mol Interv 2003; 3: 264-72.

38 Choi DJ, Koch WJ, Hunter JJ, Rockman HA. Mechanism of $\beta$-adrenergic receptor desensitization in cardiac hypertrophy is increased $\beta$-adrenergic receptor kinase. J Biol Chem 1997; 272 : 17223-9.

39 Perrino C, Naga Prasad SV, Schroder JN, Hata JA, Milano C, Rockman HA. Restoration of $\beta$-adrenergic receptor signaling and contractile function in heart failure by disruption of the $\beta A R K 1 /$ phosphoinositide 3-kinase complex. Circulation 2005; 111: 2579-87.

40 Ungerer M, Kessebohm K, Kronsbein K, Lohse MJ, Richardt G. Activation of $\beta$-adrenergic receptor kinase during myocardial ischemia. Circ Res 1996; 79: 455-60.

41 Gros R, Benovic JL, Tan CM, Feldman RD. G-protein-coupled receptor kinase activity is increased in hypertension. J Clin Invest 1997; 99: 2087-93.

42 Daaka Y, Luttrell LM, Lefkowitz RJ. Switching of the coupling of the $\beta_{2}$-adrenergic receptor to different $G$ proteins by protein kinase $A$. Nature 1997; 390: 88-91.

43 Zhu W, Petrashevskaya N, Ren S, Zhao A, Chakir K, Gao E, et al. Gibiased $\beta_{2} A R$ signaling links GRK2 upregulation to heart failure. Circ Res 2011. doi: 10.1161/CIRCRESAHA.111.253260.

44 Rockman HA, Chien KR, Choi DJ, laccarino G, Hunter JJ, Ross J Jr, et al. Expression of a $\beta$-adrenergic receptor kinase 1 inhibitor prevents the development of myocardial failure in gene-targeted mice. Proc Natl Acad Sci U S A 1998; 95: 7000-5.

45 Lymperopoulos A, Rengo G, Gao E, Ebert SN, Dorn GW 2nd, Koch WJ. Reduction of sympathetic activity via adrenal-targeted GRK2 gene deletion attenuates heart failure progression and improves cardiac function after myocardial infarction. J Biol Chem 2010; 285: 1637886.

46 Chakir K, Daya SK, Aiba T, Tunin RS, Dimaano VL, Abraham TP, et al. Mechanisms of enhanced $\beta$-adrenergic reserve from cardiac resynchronization therapy. Circulation 2009; 119: 1231-40.

47 Koch WJ, Rockman HA, Samama P, Hamilton RA, Bond RA, Milano $\mathrm{CA}$, et al. Cardiac function in mice overexpressing the $\beta$-adrenergic receptor kinase or a BARK inhibitor. Science 1995; 268: 1350-3.

48 Tachibana H, Naga Prasad SV, Lefkowitz RJ, Koch WJ, Rockman HA. Level of $\beta$-adrenergic receptor kinase 1 inhibition determines degree of cardiac dysfunction after chronic pressure overload-induced heart failure. Circulation 2005; 111: 591-7.

49 Xiao RP, Zhang SJ, Chakir K, Avdonin P, Zhu W, Bond RA, et al. Enhanced $G_{i}$ signaling selectively negates $\beta_{2}$-AR- but not $\beta_{1}$-ARmediated positive inotropic effect in myocytes from failing rat hearts. Circulation 2003; 108: 1633-9.

50 laccarino G, Tomhave ED, Lefkowitz RJ, Koch WJ. Reciprocal in vivo regulation of myocardial $\mathrm{G}$ protein-coupled receptor kinase expression by $\beta$-adrenergic receptor stimulation and blockade. Circulation 1998; 98: $1783-9$.

51 White DC, Hata JA, Shah AS, Glower DD, Lefkowitz RJ, Koch WJ. Preservation of myocardial $\beta$-adrenergic receptor signaling delays the development of heart failure after myocardial infarction. Proc Natl Acad Sci U S A 2000; 97: 5428-33.

52 Harding VB, Jones LR, Lefkowitz RJ, Koch WJ, Rockman HA. Cardiac $\beta A R K 1$ inhibition prolongs survival and augments $\beta$ blocker therapy in a mouse model of severe heart failure. Proc Natl Acad Sci U S A 2001; 98: 5809-14.

53 Sigmund $\mathrm{M}$, Jakob $\mathrm{H}$, Becker $\mathrm{H}$, Hanrath $\mathrm{P}$, Schumacher $\mathrm{C}$, Eschenhagen $\mathrm{T}$, et al. Effects of metoprolol on myocardial $\beta$-adrenoceptors and $\mathrm{G}_{\mathrm{i \alpha}}$-proteins in patients with congestive heart failure. Eur J Clin 
Pharmacol 1996; 51: 127-32.

54 Terpstra GK, Raaijmakers JA, Wassink GA. Propranolol-induced bronchoconstriction: a non-specific side-effect of $\beta$-adrenergic blocking therapy. Eur J Pharmacol 1981; 73: 107-8.

55 Eliasson K, Lins LE, Sundqvist K. Vasospastic phenomena in patients treated with $\beta$-adrenoceptor blocking agents. Acta Med Scand Suppl 1979; 628: 39-46.

56 CIBIS-II Investigators and Committees. The Cardiac Insufficiency Bisoprolol Study II (CIBIS-II): a randomised trial. Lancet 1999; 353: 9-13.

57 MERIT-HF Study Group. Effect of metoprolol CR/XL in chronic heart failure: Metoprolol CR/XL Randomised Intervention Trial in-Congestive Heart Failure (MERIT-HF). Lancet 1999; 353: 2001-7.

58 Packer M, Coats AJS, Fowler MB, Katus HA, Krum H, Mohacsi P, et al. Effect of carvedilol on survival in severe chronic heart failure. $N$ Engl J Med 2001; 344: 1651-8

59 Poole-Wilson PA, Swedberg K, Cleland JG, Di Lenarda A, Hanrath P, Komajda $\mathrm{M}$, et al. Comparison of carvedilol and metoprolol on clinical outcomes in patients with chronic heart failure in the Carvedilol Or Metoprolol European Trial (COMET): randomised controlled trial. Lancet 2003; 362: 7-13.

60 Metra M, Cas LD, Di Lenarda A, Poole-Wilson P. B-blockers in heart failure: Are pharmacological differences clinically important? Heart Fail Rev 2005; 9: 123-30.

61 Zhou Q, Xiao J, Jiang D, Wang R, Vembaiyan K, Wang A, et al. Carvedilol and its new analogs suppress arrhythmogenic store overload-induced $\mathrm{Ca}^{2+}$ release. Nat Med 2011; 17: 1003-9.

62 Wisler JW, DeWire SM, Whalen EJ, Violin JD, Drake MT, Ahn S, et al. A unique mechanism of $\beta$-blocker action: carvedilol stimulates $\beta$-arrestin signaling. Proc Natl Acad Sci U S A 2007; 104: 16657-62.

$63 \mathrm{Kim}$ IM, Tilley DG, Chen J, Salazar NC, Whalen EJ, Violin JD, et al. $\beta$-blockers alprenolol and carvedilol stimulate $\beta$-arrestin-mediated EGFR transactivation. Proc Natl Acad Sci U S A 2008; 105: 1455560.

64 Noma T, Lemaire A, Naga Prasad SV, Barki-Harrington L, Tilley DG, Chen J, et al. $\beta$-arrestin-mediated $\beta_{1}$-adrenergic receptor transactivation of the EGFR confers cardioprotection. J Clin Invest 2007; 117: 2445-58.

65 Violin JD, Lefkowitz RJ. $\beta$-Arrestin-biased ligands at seven-transmembrane receptors. Trends Pharmacol Sci 2007; 28: 416-22.

66 Ahn S, Shenoy SK, Wei H, Lefkowitz RJ. Differential kinetic and spatial patterns of $\beta$-arrestin and $G$ protein-mediated ERK activation by the angiotensin II receptor. J Biol Chem 2004; 279: 35518-25.

67 Kenakin T. Principles: Receptor theory in pharmacology. Trends Pharmacol Sci 2004; 25: 186-92.

68 Urban JD, Clarke WP, Zastrow MV, Nichols DE, Kobilka B, Weinstein $\mathrm{H}$, et al. Functional selectivity and classical concepts of quantitative pharmacology. Pharmacology 2007; 320: 1-13.

69 Mailman RB. GPCR functional selectivity has therapeutic impact. Trends Pharmacol Sci 2007; 28: 390-6.

70 Kenakin T. Collateral efficacy in drug discovery: taking advantage of the good (allosteric) nature of 7TM receptors. Trends Pharmacol Sci 2007; 28: 407-15.

71 Gong H, Sun H, Koch WJ, Rau T, Eschenhagen T, Ravens U, et al. Specific $\beta_{2} A R$ blocker ICl 118,551 actively decreases contraction through a $G_{i}$-coupled form of the $\beta_{2} A R$ in myocytes from failing heart. Circulation 2002; 105: 2497-503.

72 Bond RA, Leff P, Johnson TD, Milano CA, Rockman HA, McMinn TR. Physiological effects of inverse agonists in transgenic mice with myocardial overexpression of the $\beta_{2}$-adrenoceptor. Nature 1995; 374 : 272-6.

73 Ahmet I, Krawczyk M, Heller P, Moon C, Lakatta EG, Talan MI.
Beneficial effects of chronic pharmacological manipulation of $\beta$-adrenoceptor subtype signaling in rodent dilated ischemic cardiomyopathy. Circulation 2004; 110: 1083-90.

74 Ahmet I, Lakatta EG, Talan M. Pharmacological stimulation of $\beta_{2}$ adrenergic receptors $\left(\beta_{2} A R\right)$ enhances therapeutic effectiveness of $\beta_{1}$ AR blockade in rodent dilated ischemic cardiomyopathy. Heart Fail Rev 2005; 10: 289-96.

75 Ahmet I, Krawczyk M, Zhu W, Woo AY, Morrell C, Poosala S, et al. Cardioprotective and survival benefits of long-term combined therapy with $\beta_{2} A R$ agonist and $\beta_{1} A R$ blocker in dilated cardiomyopathy postmyocardial infarction. J Pharmacol Exp Ther 2008; 325: 491-9.

76 Ahmet I, Morrell C, Lakatta EG, Talan MI. Therapeutic efficacy of a combination of a $\beta_{1}$-adrenoreceptor (AR) blocker and $\beta_{2}-A R$ agonist in a rat model of postmyocardial infarction dilated heart failure exceeds that of a $\beta_{1}$-AR blocker plus angiotensin-converting enzyme inhibitor. J Pharmacol Exp Ther 2009; 331: 178-85.

77 Beigi F, Bertucci C, Zhu W, Chakir K, Wainer IW, Xiao RP, et al. Enantioselective separation and online affinity chromatographic characterization of R,R- and S,S-fenoterol. Chirality 2006; 18: 822-7.

78 Jozwiak K, Khalid C, Tanga MJ, Berzetei-Gurske I, Jimenez L, Kozocas $\mathrm{JA}$, et al. Comparative molecular field analysis of the binding of the stereoisomers of fenoterol and fenoterol derivatives to the $\beta_{2}$ adrenergic receptor. J Med Chem 2007; 50: 2903-15.

79 Woo AY, Wang TB, Zeng X, Zhu W, Abernethy DR, Wainer IW, et al. Stereochemistry of an agonist determines coupling preference of $\beta_{2}$-adrenoceptor to different $G$ proteins in cardiomyocytes. Mol Pharmacol 2009; 75: 158-65.

80 Seifert R, Dove S. Functional selectivity of GPCR ligand stereoisomers: new pharmacological opportunities. Mol Pharmacol 2009; 75: 13-8.

81 Jozwiak K, Woo AY, Tanga MJ, Toll L, Jimenez L, Kozocas JA, et al. Comparative molecular field analysis of fenoterol derivatives: $A$ platform towards highly selective and effective $\beta_{2}$-adrenergic receptor agonists. Bioorg Med Chem 2010; 18: 728-36.

82 Talan MI, Ahmet I, Xiao RP, Lakatta EG. $\beta_{2} A R$ in the treatment of congestive heart failure: long path to translation. J Mol Cell Cardiol 2011; 51: 529-33.

83 Mangmool S, Shukla AK, Rockman HA. B-Arrestin-dependent activation of $\mathrm{Ca}^{2+} /$ calmodulin kinase II after $\beta_{1}$-adrenergic receptor stimulation. J Cell Biol 2010; 189: 573-87.

84 Zhu W, Woo AY, Yang D, Cheng H, Crow MT, Xiao RP. Activation of $\mathrm{CaMKII}_{\overline{0}} \mathrm{C}$ is a common intermediate of diverse death stimuli-induced heart muscle cell apoptosis. J Biol Chem 2007; 282: 10833-9.

85 Ling H, Zhang T, Pereira L, Means CK, Cheng H, Gu Y, et al. Requirement for $\mathrm{Ca}^{2+} /$ calmodulin-dependent kinase II in the transition from pressure overload-induced cardiac hypertrophy to heart failure in mice. J Clin Invest 2009; 119: 1230-40.

86 Van Oort RJ, McCauley MD, Dixit SS, Pereira L, Yang Y, Respress JL, et al. Ryanodine receptor phosphorylation by calcium/calmodulindependent protein kinase II promotes life-threatening ventricular arrhythmias in mice with heart failure. Circulation 2010; 122: 266979.

87 Chen H, Ma N, Xia J, Liu J, Xu Z. $\beta_{2}$-adrenergic receptor-induced transactivation of EGFR and PDGFR via SRC kinase promotes rat cardiomyocytes survival. Cell Biol Int 2011. doi:10.1042/CBI20110162.

88 Stuenaes JT, Bolling A, Ingvaldsen A, Rommundstad C, Sudar E, Lin $\mathrm{FC}$, et al. $\beta 2$-Adrenoceptor stimulation potentiates insulin-stimulated $\mathrm{PKB}$ phosphorylation in rat cardiomyocytes via cAMP and PKA. $\mathrm{Br} \mathrm{J}$ Pharmacol 2010; 160: 116-29.

89 Morisco C, Condorelli G, Trimarco V, Bellis A, Marrone C, Condorelli G, et al. Akt mediates the cross-talk between $\beta$-adrenergic and insulin receptors in neonatal cardiomyocytes. Circ Res 2005; 96: 180-8. 